\title{
The Islamicity of Sharia Rural Banks in Indonesia
}

\author{
Imanda Firmantyas Putri Pertiwi $^{{ }^{*}}$, Indriyana Puspitosari ${ }^{2}$, Fitri Laela Wijayati ${ }^{3}$ \\ ${ }^{1}$ IAIN Salatiga, Indonesia, ${ }^{2,3}$ IAIN Surakarta, Indonesia
}

Submitted: 21 June, 2019; Accepted: 10 March, 2020; Published: 15 March, 2020

\begin{abstract}
This paper is aimed to evaluate the Islamic Performance of Sharia Rural Banks (SRBs) in Indonesia by using the Islamicity Performance Index (IPI). The data are taken from SRBs from 2014 to 2016 (those include PF and Profit), as well as the liquidation of SRBs in those years. The sample is taken using a purposive sampling technique. Then, there are 82 SRBs samples and observing 246 pcs data. The data are obtained by evaluating their financial reports through the websites of Central Bank of Indonesia or Financial Services Authority (Otoritas Jasa Keuangan-OJK) as well as the SRBs websites. The data are analyzed by non-statistic quantitative and descriptive qualitative techniques. The results are gained from each indicator of their average Islamic Performance Index. The result shows that the Islamic Performance Index of Sharia Rural Banks is unsatisfied. Henceforth, this study has several limitations that may be observed in the next research. Moreover, this research excludes the welfare indicators of the directoremployee and AAOIFI index.
\end{abstract}

Keywords: islamicity, sharia rural banks, islamicity performance index

\begin{abstract}
Abstrak
Penelitian ini bertujuan untuk menilai kinerja keislaman (Islamicity) Bank Perkreditan Rakyat Syariah (BPRS) di Indonesia. Penelitian ini menggunakan sampel BPRS di Indonesia dari tahun 2014 hingga 2016, dengan menggunakan teknik purposive sampling. Sampel akhir yang diperoleh adalah 82 SRB sehingga data yang diamati adalah $246 \mathrm{pcs}$ data. Data diperoleh dengan mengakses laporan keuangan mereka melalui situs web Bank Sentral Indonesia atau Otoritas Jasa Keuangan (OJK) serta situs web masing-masing BPRS. Penelitian ini dianalisa dengan menggunakan teknik kuantitatif non-statistik dan deskriptif kualitatif. Hasil penelitian menemukan bahwa kinerja bank syariah berdasarkan Indeks kinerja keislaman adalah "tidak memuaskan". Bagaimanapun, penelitian ini memiliki beberapa batasan yang dapat diperoleh melalui penelitian selanjutnya. Penelitian ini tidak termasuk indikator kesejahteraan direktur-karyawan dan indeks AAOIFI.
\end{abstract}

Kata kunci: keislaman, bank perkreditan rakyat syariah, indeks kinerja keislaman

\footnotetext{
* Corresponding author 


\section{INTRODUCTION}

According to the statistical data of quantity, assets, the return of an asset, and thirdparty funds, the development of Sharia Rural Banks (SRBs) in Indonesia is quite promising. However, the performances of SRBs' profit and Non-Performing Financing (NPF) aspects seem tough. As the result, SRB profits decline quite significantly. The declining profits from 2016 to 2017 are affected by NPF, which easily inclined around $2.13 \%$ compared to the previous year.

Table 1. Sharia Banking Statistics

\begin{tabular}{llcccccc}
\hline No & & $\mathbf{2 0 1 2}$ & $\mathbf{2 0 1 3}$ & $\mathbf{2 0 1 4}$ & $\mathbf{2 0 1 5}$ & $\mathbf{2 0 1 6}$ & $\mathbf{2 0 1 7}$ \\
\hline 1. & Numbers & 158 & 163 & 163 & 163 & 166 & 167 \\
\hline 2. & Asset & $4,7 \mathrm{~T}$ & $6,3 \mathrm{~T}$ & $6,7 \mathrm{~T}$ & $7,8 \mathrm{~T}$ & $9,2 \mathrm{~T}$ & $9,9 \mathrm{~T}$ \\
\hline 3. & Profit & $106 \mathrm{M}$ & $129 \mathrm{M}$ & $121 \mathrm{M}$ & $137 \mathrm{M}$ & $159 \mathrm{M}$ & $108 \mathrm{M}$ \\
\hline 4. & NPF & $6,16 \%$ & $6,60 \%$ & $7,89 \%$ & $8,20 \%$ & $8,65 \%$ & $10,78 \%$ \\
\hline 5. & ROA & $2,64 \%$ & $2,79 \%$ & $2,26 \%$ & $2,20 \%$ & $2,27 \%$ & $2,50 \%$ \\
\hline 6. & DPK & $2,9 \mathrm{~T}$ & $5,7 \mathrm{~T}$ & $4,0 \mathrm{~T}$ & $4,3 \mathrm{~T}$ & $5,8 \mathrm{~T}$ & $6,3 \mathrm{~T}$ \\
\hline 7. & Financing & $3,7 \mathrm{~T}$ & $4,4 \mathrm{~T}$ & $6,0 \mathrm{~T}$ & $6,8 \mathrm{~T}$ & $6,7 \mathrm{~T}$ & $7,5 \mathrm{~T}$ \\
\hline
\end{tabular}

Source: OJK (2017)

Low financial performance in 2017 requires serious attention. Previously, Bank Indonesia has set up the NPF safety limit at 5\%(Bank Indonesia, 2011). It means that if the NPF of SRBs meets twice as its limit, the SRB management system should be fixed. Maulana (Kompasiana, May 24, 2017) states that SRBs are seen insolvency. Eight conventional and Sharia Rural Banks are liquidated by the Financial Services Authority (OJK) from 2015 to April 2016. Two of them are SRB Hidayah Jakarta and SRB Al Hidayah Pasuruan, East Java. The reason for the liquidation is; first, there is a fraud, and the second is mismanagement. Furthermore, another SRB that liquidated is SRB Shadiq Amanah in September 2016 (LPS, 2017).

Based on the above table, if we examine the funding aspect (third-party funds), we can conclude that people's trust in SRBs is on the increase. Compare to the last two years, people's trust in the maintenance performance of SRBs is to descend. It shows from the fact that NPF increases while SRBs are liquidated. Keeping people's trust shall be the main priority of Sharia Rural Banks. Furthermore, the addition of the word "sharia” becomes Sharia Rural Banks, shall perform more in Islamic aspects. Then how to measure the Islamic Performance of these Rural Banks? 
The question would be answered by analyzing 167 SRBs in Indonesia through Islamicity Performance Index (IPI) analysis. Islamicity Performance Index is initiated by Hameed and Alrazi (2004). Their main idea of Islamicity is how to evaluate sharia bank performance, not only in terms of financial aspects but also in the principles of justice, lawfulness, and purification. There are seven ratios of Islamicity Performance Index (IPI), namely profit sharing ratio, zakat performance ratio, equitable distribution ratio, directoremployee welfare ratio, Islamic investment vs. non-Islamic investment ratio, Islamic income vs. non-Islamic income and AAOIFI Index (Meilani, Rahmayati, \& Andraeny, 2014).

This research only elaborates five ratios out of seven ratios, which left the directoremployee welfare ratio and AAOIFI Index. Hence, the director-employee welfare ratio is formulated by the total welfare of the board directors compared to the income earned by the employees. This ratio excludes from this research due to the limited access to the directors' salary.

\section{Stakeholder Theory and Sharia Enterprise Theory}

According to Guthrie, Petty, and Ricceri (2006), the financial report is the most efficient way for an organization to communicate with stakeholder groups, which have an interest in controlling specific organizational strategic aspects (referring to the stakeholder theory). The primary purpose of the stakeholder theory is that to corporate accountability, and it does not limit its pure economic or financial performance. This means that organizations should voluntarily disclose information about their intellectual, social, and environmental achievements to perceive stakeholder expectations.

However, compare to Sharia Enterprise Theory, Islamic performance reports, which include in Islamic Performance Index, highlight the trust to both stakeholders and God, the Supreme Giver of Mandate. The sharia enterprise theory is a corporate theory that is internalized with the value of Godhead. The most important axiom of this theory is God as the Creator and the Owner of all existing resources in the world. The human being is only temporarily in this world, so that the company ought to use resources as God's commands(Meutia, 2010).

The sharia enterprise theory has an idea that the distribution of wealth or other valuable goods not only directly applies to the evolved participants or those who contribute to company operations, such as shareholders, creditors, employees, and the government; but also other parties that are not directly related to the business conducted by the company, or those who do not contribute financially or skillfully. The scope of accounting of sharia enterprise theory is not limited to events that are reciprocal between the direct-involved parties and other indirect- 
uninvolved parties. This concept certainly brings the essential changes in the terminology of the enterprise theory, which lays down its premise to distribute wealth based on the contributions of the participants, i.e., participants who contribute financially or skillfully .

\section{Islamic Performance Index}

Islamic Performance Index (IPI) is a method used to describe the operational performance of Sharia Banks (Islamicity) and to find out whether the performance has met the set principles of sharia or not (Hameed \& Alrazi, 2004). There are seven indicators of the Islamic Performance Index which describe the performance of sharia banks. The first is the Profit-Sharing Ratio (PSR). The typical characteristic of the Sharia Bank, which is differentiated from the conventional banks, is the principle of profit/loss sharing. Sharia Banks' have the principle of mudharabah and musharakah schemes. Mudharabah and musharakah are two forms of products with sharing-based contracts that are widely mentioned in fiqh (Islamic Jurisprudence) literature. These equity-based products are unique and superior to conventional banking for ethical and efficiency reasons. These products are considered to be the recent concept of Islamic banking based on the idea that Islam disallows riba, but allows trade arrangements along with the distribution of profits and losses (Febianto, 2017).

The second is the Zakat Performance Ratio (ZPR). The Sharia Bank performance, according to Hameed and Alrazi (2004), should be conducted more precisely based on the zakat payment. The Zakat Performance Ratio is the ratio of the financial performance of Islamic banks that measures how much zakat is issued by a bank and how the bank compares it to Net Assets (Aisjah \& Hadianto, 2013). Assets of banks, which are commonly emphasized by conventional banks, must be based on their net assets rather than net profit. Therefore, when net assets are higher than the zakat payment, so it will be higher as well. Net assets are calculated from the total assets deducted by the total liabilities as denominators for this Zakat Performance Ratio. If generated ZPR value is small, it means that the charity is still low as compared to the total of net assets.

The third is the Equitable-Distribution Ratio (EDR). The primary purpose of Islamic accounting is to ensure the equitable distribution of all parties' income. In addition to profitsharing activities between banks and customers, income distribution to various stakeholders is also an important issue. EDR indicator is used to determine the income distribution of sharia banks to their stakeholders. In this case, the stakeholders are employees, investors, communities, and corporates. The income has been deducted by zakat and tax. Fourth, the 
Director-Employee Welfare Ratio (DER). The director-employee welfare ratio indicates the total amount of money which is spent on the directors' salaries and facilities compared to the total amount of money on the employees' welfare. This is due to the director's remuneration issues, revealing that the director is paid more than what he did, while the employees are paid less than what they deserve. This ratio is used to compare the welfare earned by the board of directors to the employees (Hameed \& Alrazi, 2004)

The fifth is the Islamic Investment vs. Non-Islamic Investment (INIv). The place to invest funds of Islamic banks is required only in the halal sector, and by considering the sources of revenues obtained from investments based on either wadiah, mudharabah-mutlaqah, or mudharabah-muqayyadah as well as government programs (Lutfiandari \& Septiarini, 2016). Islamic Investment vs. non-Islamic Investment constitutes a ratio that compares lawful Islamic investment to total investment, which is done by sharia banks entirely (lawful/halal and nonlawful/haram)(Wiyadi, Meilani, Trisnawati, \& Pramesti, 2016).

The sixth is Islamic Income vs. Non-Islamic Income (INIc). Islamic banking must only receive income from halal sources. In case that the Islamic bank earns some income from nonhalal transactions, the bank should disclose the information such as amount, source, how to determine it, and the most important is the availability procedures to prevent the entry of transactions from unauthorized by sharia(Prasetya, 2011). The income of Sharia Banks should not contain three elements of riba, gambling, and deception. The INIc ratio aims to measure the income from halal sources. This INIc ratio is to determine the proper income in line with Islamic principles (Meilani et al., 2014). The last is the AAOIFI Index. AAOIFI is the Islamic Accounting Standard for the Islamic Financial Institution. Thus, the Islamic Bank should comply with it, although the law does not require it. AAOIFI index is used to determine the extent to which sharia financial institutions meet the principles that already set off by The Accounting and Auditing Organization for Islamic Financial Institutions (AAOIFI) (Hameed \&Alrazi, 2004). 


\section{Sharia Rural Banks (SRBs) in Indonesia}

Islamic banking has a strategic role in improving the welfare of the community through the intermediation process of collecting and distributing funds as well as providing other financial services based on sharia principles. There are many forms of Islamic banking in Indonesia, such as Sharia Commercial Banks, Sharia Business Units, and Sharia Rural Banks. The regulations on SRBs in Indonesia are stated in POJK no.3/POJK 03/2016 which concern to Sharia Rural Banks (OJK, 2016), and the corporate governance of Sharia Rural Banks is regulated in OJK regulation POJK no.24/POJK3/ 2018(OJK, 2018).

The earliest establishment of Sharia Rural Banks (SRBs) in Indonesia becomes the pioneer of the first establishment of Sharia Bank. Three initial SRBs were established in 1990, i.e., BPR Dana Mardhatillah in Margahayu Sub-district, Bandung, BPR Berkah Amal Sejahtera in Padalarang Sub-district, Bandung, and BPR Amanah Rabbaniyah in Banjaran Sub-district, Bandung. The performances of those three SRBs have been acknowledged by the Indonesian Minister of Finance(Daud, 2014).

There are 167 SRBs existed in Indonesia in 2017. Contrarily, the highlighted case from 2015 - 2016 is that SRBs have been found liquidated (so far, six SRBs have a similar situation). This case becomes an interesting phenomenon to be investigated and evaluated.

\section{METHOD}

\section{Population and Sample}

The population in this research is 167 registered and existed SRBs in Indonesia. This research uses the purposive technique to find sampling. The criteria are determined by registered SRBs from 2014-2016, and SRBs whose their financial reports are accessible through websites of Bank Indonesia or OJK as well as their websites. The observed data are taken from the number of qualified SRBs in the past three years (starting from 2014-2016). However, for SRBs which are already liquidated in 2016, then their financial reports are examined on the last month or quarterly reports before the liquidation of the rural banks.

\section{Variables}

a. Profit-Sharing Ratio (PSR)

$$
P S R=\frac{\text { Mudarabah }+ \text { Musyarakah }}{\text { Total Financing }}
$$


b. Zakat Performance Ratio (ZPR)

$$
Z P R=\frac{\text { Zakat }}{\text { Net Asset }}
$$

c. Equitable Distribution Ratio (EDR)

$$
\begin{gathered}
E D R=\frac{\text { The Average Distribution for Each Stakeholders }}{\text { Total Revenue }} \\
\text { Qardh and Donation }=\frac{\text { Qardh and Donations }}{\text { Revenue }-(\text { Zakat }+ \text { Tax })} \\
\text { Employees Expenses }=\frac{\text { Employees Expenses }}{\text { Revenue }-(\text { Zakat }+ \text { Tax })} \\
\text { Shareholders }=\frac{\text { Deviden }}{\text { Revenue }-(\text { Zakat }+ \text { Tax })} \\
\text { Net Profit }=\frac{\text { Net Profit }}{\text { Revenue }-(\text { Zakat }+ \text { Tax })}
\end{gathered}
$$

d. Islamic vs. Non-Islamic Investment (INIv)

$$
I N I v=\frac{\text { Halal Investment }}{\text { Halal Investment }+ \text { Non }- \text { Halal Investment }}
$$

e. Islamic vs. Non-Islamic Income (INIc)

$$
I N I c=\frac{\text { Halal Revenue }}{\text { Halal Revenue }+ \text { Non }- \text { Halal Revenue }}
$$

\section{Data Analysis Techniques}

The data in this research are analyzed by quantitative non-statistical and descriptive qualitative techniques. Non-statistical quantitative method is a method for analyzing data in the form of numbers without testing them statistically. The descriptive qualitative method is a method of analyzing data by providing explanations with words or sentences to explain the quantitative data to conclude (Sugiyono, 2008).

The results from each indicator of determining the Islamic performance index are the average of all Indonesian sharia rural banks. Subsequently, they are compared to find the trend from 2014 up to 2016. According to Aisjah and Hadianto (in Meilani, et al, 2014) to obtain the average value, the analysis should be done by the following steps :

Table 2. The Predicate of Islamic Performance Index

\begin{tabular}{ll}
\hline Average Score & Predicate \\
\hline $0 \leq \mathrm{x} \leq 1$ & Very Unsatisfied \\
\hline $1 \leq \mathrm{x} \leq 2$ & Unsatisfied \\
\hline $2 \leq \mathrm{x} \leq 3$ & Less Satisfied \\
\hline $3 \leq \mathrm{x} \leq 4$ & Satisfied Enough \\
\hline $4 \leq \mathrm{x} \leq 5$ & Satisfied \\
\hline $\mathrm{X}=5$ & Very Satisfied \\
\hline
\end{tabular}

Source: Aisjah and Hadianto (2013) 


\section{RESULTS AND DISCUSSION}

This research uses Indonesian SRBs samples from 2014 to 2016. By using purposive sampling techniques, the final samples are 82 SRBs. The observed data in this study are $82 \times 3$ years $=246$ pcs of data. The selectional process is done based on the following criteria, as figured out in Table 3 below.

Table 3. Sample Criteria

\begin{tabular}{lc}
\hline \multicolumn{1}{c}{ Criteria of SRBs } & $\begin{array}{c}\text { Numbers } \\
\text { of SRB }\end{array}$ \\
\hline Existing SRBs in Indonesia in from 2014 to 2016 & 167 \\
\hline $\begin{array}{l}\text { SRBs without accessible financial reports on websites of BI or OJK, } \\
\text { or their websites respectively }\end{array}$ & 84 \\
\hline Sum of SRB samples & 82 \\
\hline Sum of observed data $(82 \times 3)$ & 246 \\
\hline
\end{tabular}

Source: Data Processed

\section{Profit-Sharing Ratio (PSR)}

Profit-Sharing Ratio (PSR) is used to compare the profit between the financing profitsharing and the total financing. This action becomes a successful standard in practicing the profit-sharing principles, which are fundamental principles of sharia banking (Meilani et al., 2014). This ratio is urgent to be evaluated because of profit-share financing, as listed in musharakah and mudharabah agreement as to the typical characteristics of sharia banks and sharia rural banks, which differentiate from conventional banks. Profit share financing includes in the uncertain contract, i.e., financing agreement without fixed profits and depending on the business partner's conditions.

Table 4. The Average of SRB Profit Sharing Ratio (PSR) in Indonesia

\begin{tabular}{rrrr}
\hline & \multicolumn{3}{c}{ Years } \\
\cline { 2 - 4 } & 2014 & 2015 & 2016 \\
\hline Average Value & $12.12 \%$ & $11.51 \%$ & $13.69 \%$ \\
\hline
\end{tabular}

Source: Processed Data

Based on the Profit Sharing Ratio (PSR), it is noted that profit share funding has fluctuated rapidly over three years. In 2014-2015, the PSR of SRBs decline by $0.61 \%$. This implies that SRB performance, as noticed by their profit share funding, already decline from 2014 to 2015. Compared to mudharabah and musyarakah transactions in 2014, they uncertainly pass the contract agreements in which SRBs' made in 2015. 
It is observed that only a few SRBs make a profit of share funding from 2014 to 2015. In 2014, 65 SRBs in Indonesia carried out uncertain contracts (mudharabah and musharakah). Whereas in 2015, 62 SRBs are agreed to this contract. From 2015 to 2016, Profit Sharing Ratio (PSR) inclines up to $2.18 \%$. Therefore, SRBs pass the uncertain funding contracts (mudarabah and musharakah) than specific previous contracts (murabahah, istishna, salam, and ijarah). So, the profit share funding portion increases from 2015 to 2016.

\section{Zakat Performance Ratio (ZPR)}

The Zakat Performance Ratio (ZPR) constitutes a ratio measuring the amount of zakat paid by SRBs when scaled by the net assets.

Table 5. Average of SRB Zakat Performance Ratio (ZPR) in Indonesia

\begin{tabular}{crrr}
\hline & \multicolumn{3}{c}{ Years } \\
\cline { 2 - 4 } & 2014 & 2015 & 2016 \\
\hline Average Value & $0.02 \%$ & $0.01 \%$ & $0.01 \%$
\end{tabular}

Source: Processed Data

Based on the analysis of SRB financial reports, it is found that out of 82 SRBs, 62 of them do not reveal the amount of zakat which they have paid from 2014 to 2016 . The results of this ratio assessment show that paying zakat of SRBs is getting lower from 2014 to 2015 and stagnant in 2016. This implies that SRBs do not seriously undertake to pay zakat. The rate of zakat payment is below 2.5\%. The amount of zakat payment in Indonesia is relatively small. This is, of course, inappropriate with tazkiyah (purification) principle, i.e., the higher net assets are gained, the more zakat should be paid. This phenomenon creates a further question of whether SRBs failed to pay their zakat for their business operations, or they merely ignore it as part of reporting the assets. This case would be examined in the next research.

\section{Equitable Distribution Ratio(EDR)}

The Equitable Distribution Ratio constitutes a ratio to determine the percentage of the distributed revenue to various stakeholders; in this case, the expenses for qardh (loan) and donation, employees, and others. Each element of the ratio is calculated by determining the distributed amount (to society, employees, investors, and company), and then divided by total income and reduced by zakat and tax payment. 
Table 6. Average of SRB Qardh and Donation Equitable Distribution Ratio (EDR)

\begin{tabular}{crrr}
\hline & \multicolumn{3}{c}{ Years } \\
\cline { 2 - 4 } & 2014 & 2015 & 2016 \\
\hline Average Value & $0.00 \%$ & $0.00 \%$ & $0.00 \%$ \\
\hline
\end{tabular}

Source: Processed Data

The results of the analysis on SRB financial reports indicate that all 82 SRBs do not assert the amount of income in which they have to distribute to the stakeholders in the forms of qardh (loan) and donation in the period 2014 to 2016. This means that SRBs do not optimally pay attention to several social aspects because the rate of distributed income of qardh and donation, which reflected SRB social responsibility, is still zero.

Table 7. The Average of SRB Employee Expenses Equitable Distribution Ratio (EDR)

\begin{tabular}{rrrr}
\hline & \multicolumn{3}{c}{ Years } \\
\cline { 2 - 4 } & 2014 & 2015 & 2016 \\
\hline Average Value & $0.000027 \%$ & $0.000030 \%$ & $0.000068 \%$ \\
\hline
\end{tabular}

Source: Processed Data

Based on the research, it is noted that the amount of income distributed for SRB employees is quite small (less than 1\%). Furthermore, the distribution of income for the employees is rising every year. At least SRBs still provide information on the distribution of income to the employees on their financial reports, unlike EDR (qardh and donation), which are unreported. This finding notices that SRB's distribution of income for its employees is low, but it is hoped that the rate would grow. This is based on the fact that the distributed income interestingly increases from 2014 to 2016.

Table 8. Average of SRB Shareholders Dividend Equitable Distribution Ratio (EDR)

\begin{tabular}{rrrr}
\hline & \multicolumn{3}{c}{ Years } \\
\cline { 2 - 4 } & 2014 & 2015 & 2016 \\
\hline Average Value & $0.00 \%$ & $0.00 \%$ & $0.00 \%$ \\
\hline
\end{tabular}

Source: Processed Data

The results of the analysis on SRB financial reports also show that all 82 SRBs do not declare the amount of distributed income to the shareholders in the form of dividends from 2014 to 2016.

Table 9. Average of SRB Net Profit Equitable Distribution Ratio (EDR)

\begin{tabular}{crrr}
\hline & \multicolumn{3}{c}{ Years } \\
\cline { 2 - 4 } & 2014 & 2015 & 2016 \\
\hline Average Value & 0.01260 & $(0.00148)$ & $(0.11990)$ \\
\hline
\end{tabular}

Source: Processed Data

It is showed from Table 9 that in 2014 most SRBs demonstrate positive EDR net profits of 1.26\%. However, in 2015 and 2016, the average EDR net profits of SRBs shows a negative value. 
This happens because most SRBs suffered loss financially due to the inclined NPF, as previously stated, so that the obtained revenue has a negative balance. To conclude, the EDR performance of Indonesia's SRBs shows unsatisfactory results. From the four EDR indicators, the most significant attention of their distributed income is their net profits.

\section{Islamic vs. Non-Islamic Investment (INIv)}

Islamic Investment vs. non-Islamic Investment ratio represents the lawfulness aspect and the success of the basic SRBs principle, i.e., free of riba (Meilani, et al., 2014). The ratio could be measured by comparing the lawful investment to the total investment carried out by SRBs (lawful and non-lawful included).

Table 10. The Average of SRB Islamic vs Non-Islamic Investment

\begin{tabular}{crrr}
\hline & \multicolumn{3}{c}{ Years } \\
\cline { 2 - 4 } & 2014 & 2015 & 2016 \\
\hline Average Value & $0.00 \%$ & $0.00 \%$ & $0.00 \%$ \\
\hline
\end{tabular}

Source: Processed Data

The analysis of SRB financial reports find out that all 82 SRBs do not state the amount of lawful investment, which is gained from the total revenue from 2015 to 2016. Constitutional principles ought to be upheld by SRBs as one kind of sharia financial institution. The legal principles assure the implementation of the basic principle of SRBs, i.e., free of usury. SRBs need to review the importance of stating lawful and unlawful investment to get people's trust in SRBs as institutions with sharia principles.

\section{Islamic vs. Non-Islamic Income (INIc).}

Islamic vs. Non-Islamic Income (INIc) ratio is a comparison between the lawful income and the overall income earned by SRBs (lawful and non-lawful).

Table 11. The Average of SRB Islamic vs. Non-Islamic Income

\begin{tabular}{crrr}
\hline & \multicolumn{3}{c}{ Years } \\
\cline { 2 - 4 } & 2014 & 2015 & 2016 \\
\hline Average Value & $2.20 \%$ & $1.22 \%$ & $1.22 \%$ \\
\hline
\end{tabular}

Source: Processed Data

The analysis of SRB financial reports also depicts that out of 82 SRBs, only one SRB has stated the information of lawful and non-lawful income throughout 2014-2016. Then, other SRBs inform their income in 2014. These Sharia Rural Banks are SRB Gebu Prima and SRB Artha Karimah Irsyadi. In line with this fact, the Islamic vs. Non-Islamic Income ratio of SRBs remains worth enough. The ratio is getting down in 2014 and 2015 and stagnant in 2016. 


\section{Islamicity Performance Index}

Based on the above SRB performance measurement along with the subjective assessments, and Islamic Performance Index, the performance of Indonesian's SRBs are unsatisfying. The Islamic Performance Index could be seen in the table below:

Table 12. Results of Islamic Performance Index Assessment

\begin{tabular}{lll}
\hline \multicolumn{1}{c}{ Performance Assessment } & \multicolumn{1}{c}{ Score } \\
\hline Profit-sharing Ratio & Less Satisfied & $\mathbf{2}$ \\
\hline Zakat Performance Ratio & Extremely Unsatisfied & $\mathbf{1}$ \\
\hline Equitable Distribution Ratio & Unsatisfied & $\mathbf{1}$ \\
\hline Islamic vs. Non-Islamic Investment & Extremely Unsatisfied & $\mathbf{0}$ \\
\hline Islamic vs. Non-Islamic Income & Extremely Unsatisfied & $\mathbf{0}$ \\
\hline \multicolumn{2}{c}{ Total } & $\mathbf{4}$ \\
\hline \multicolumn{2}{c}{ Average } & $\mathbf{1}$ \\
\hline
\end{tabular}

Source: Processed Data

\section{CONCLUSION}

SRBs have a strategic role in improving people's welfare by practicing sharia principles. Sharia Rural Banks are a kind of Sharia Banks that exists in Indonesia. As the body of Sharia Banks, SRBs should meet the requirements of sharia regulations. Then, the Islamic Performance Index approach is an appropriate approach to analyze SRBs performances.

Islamic Performance Index constitutes a method to evaluate SRB performances not only in terms of financial but also on justice, lawfulness, and purification (tazkiyah) principles. Five ratios measure the Islamic Performance Index (IPI), i.e., Profit sharing Ratio, Zakat Performance Ratio, Equitable Distribution Ratio, Islamic vs. Non-Islamic Investment, and Islamic vs. Non-Islamic Income.

The results of this study show that throughout 2014-2016, the performance of Indonesia's SRBs is "unsatisfied" by the rate only "1". This happens because SRBs do not state the several elements to determine Islamic Performance Index ratios, for instance, Equitable Distribution Ratio, Islamic vs. Non-Islamic Investment, and Islamic vs. Non-Islamic Income. Moreover, further interviews with several SRBs are included as research subjects, it was noted that they actually had implemented several requirements of Islamic Performance Index, but they have not declared and reported as well. 


\section{LIMITATIONS AND SUGGESTIONS}

The implementation of the performance assessment based on the Islamic Performance Index is expected to be applied by SRBs to analyze their performances. Therefore, SRBs are hopefully concerned about improving their better performance. Out of five ratios that are included in the Islamic Performance Index, some of them get 0 (zero points). This is because SRBs fail to provide the information regarding the elements in which used to measure the ratios, namely: loan and donation, dividend, lawful vs. non-lawful investments, and lawful vs. Nonlawful income.

These data show the fact of unsatisfied results of the assessment on Equitable Distribution Ratio, Islamic vs. Non-Islamic Investment, and Islamic vs. Non-Islamic Income. Regarding the importance of complying with sharia principles, SRB is expected to improve its Islamic performance reports. The zakat performance ratio, as reflected by the zakat performance index for SRBs, is considered low. This point needs to be improved as well. The number of zakat expenses should be higher than before so that it can increase the community's welfare. Then, further interviews with several SRBs are included as research subjects, it was noted that they actually had implemented several requirements of Islamic Performance Index, but they have not declared and reported as well. It is suggested that SRBs may improve their reports' activities in detail, especially in dealing with financial or non-financial transactions.

Therefore, analyzing the performance of shariah financial institutions, further research is expected to expand the scope of the study, not only to focus on SRBs but also to examine other forms of shariah financial institutions like Baitul Maal wat Tamwil (BMT). Then, to analyze SRB is better to apply some methods than only using Islamicity Index.

\section{REFERENCES}

Aisjah, S., \& Hadianto, A. E. (2013). Performance-Based Islamic Performance Index ( Study on the Bank Muamalat Indonesia and Bank Syariah Mandiri). Asia-Pacific Management and Business Application, 2, 98-110.

Bank Indonesia. (2011). Peraturan Bank Indonesia Tentang Penilaian Tingkat Kesehatan BankUmum.

Daud, N. A. (2014). Bank Perkreditan Rakyat Syariah di Indonesia. Retrieved from https://syariahekonomi45.blogspot.com/2016/04/bprs-bank-pembiayaan-rakyat syariah-di.html. 
Dewanata, P., Hamidah, \& Ahmad, G. N. (2016). The Effect of Intellectual Capital and Islamicity Performance Index To the Performance of Islamic Bank in Indonesia 20102014Periods. Jurnal Riset Manajemen Sains Indonesia, 7(2), 259-278.

Febianto, I. (2017). Risk Management in Mudharabah and Musharakah Financing of Islamic Banks. 2nd Islamic Economics Conference (iEONS), 399-404.

Guthrie, J., Petty, R., \& Ricceri, F. (2006). The Voluntary Reporting of Intellectual Capital: Comparing Evidence from Hong Kong and Australia. Journal of Intellectual Capital, 7(2), 254-271. https://doi.org/10.1108/14691930610661890.

Hameed, S., \& Alrazi, B. (2004). Alternative Disclosure and Performance Measures For Islamic Banks. Second Conference on Administrative Sciences: Meeting the Challenges of the Globalization Age, King Fahd University of Petroleum \& Minerals, Dhahran, Saudi Arabia, 1-12.

Khasanah, A. N. (2016). Pengaruh Intelektual Capital dan Islamicity Performance Index Terhadap Kinerja Keuangan Perbankan Syariah di Indonesia. Jurnal Nominal, V(6), 1-18.

LPS. (2017). Lembaga Penjamin Simpanan - Bank yang Dilikuidasi.

Lutfiandari, H. A., \& Septiarini, D. F. (2016). Analisis Tren dan Perbandingan Rasio Islamicity Performance pada Bank Syariah Mandiri, Bank Muamalat Indonesia, Bank BRI Syariah dan Bank BNI Syariah Periode 2011-2014. Ekonomi Syariah, 3(6), 430- 443. https://doi.org/10.4172/2090-4886.1000128.

Maulana, I. (2017). Bank Pembiayaan Rakyat Syariah Masih Rentan Bankrut. Kompasiana.

Meilani, S. E., Rahmayati, A., \& Andraeny, D. (2014). Analisis Kinerja Perbankan Syariah di Indonesia dengan Menggunakan Pendekatan Islamicity Indices. UMS Seminar Nasional dan The 3rd Call for Syariah Paper, 22-38.

Meutia, I. (2010). The Concept of Social Responsibility Disclosures for Islamic Banks Based on Shari' ah Enterprise Theory. Jurnal Akuntansi Multiparadigma, 1(3), 361-374.

OJK. (2016). Peraturan Otoritas Jasa Keuangan Nomor 3/POJK.03/2016 Tentang Bank Pembiayaan Rakyat Syariah.

OJK. (2017). Statistik Perbankan Syariah 2017.

OJK. (2018). Peraturan Otoritas Jasa Keuangan Nomor 24/POJK.03/2018 Tentang Penerapan Tata Kelola bagi Bank Pembiayaan Rakyat Syariah. 
Prasetya, D. N. (2011). Analisis Pengaruh Intellectual Capital Terhadap Islamicity Financial Performance Index Bank Syariah di Indonesia. Retrieved from http://eprints.undip.ac.id/29668/1/Skripsi001.pdf.Sugiyono. (2008). Metode Penelitian Pendidikan:(Pendekatan Kuantitatif, Kualitatif dan $R$ \& D). Bandung: Alfabeta.

Triyuwono, I. (2001). Metafora Zakat dan Shari'ah Enterprise Theory Sebagai Konsep Dasar Dalam Membentuk Akuntansi Syari'ah. Jurnal Akuntansi dan Auditing Indonesia, 5(2), $131-145$. 